\title{
Tiedettä kotimaisilla kielillä
}

\author{
Nika Potinkara ja Niina Hämäläinen
}

$\mathrm{S}$ uomen kielen lautakunta esitti tämän vuoden lokakuussa poikkeuksellisen jyrkkäsanaisen kannanoton: suomen ja ruotsin kielet ovat Suomessa vakavasti uhattuina. Kielinä suomi ja ruotsi eivät ole uhanalaisia - ne kuuluvat maailman kielten joukossa puhujamääriltään suurimpaan kahteen prosenttiin - mutta niiden rooli yhteiskunnassa on kapenemassa. Ruotsin kielen asema on Suomessa jo ennestään varsin heikko, ja myös suomen käyttöala kapenee nopeasti, kun työelämässä käytetään yhä enemmän englantia. (Kotimaisten kielten keskus 2018.) Pessimistisimpien arvioiden mukaan suomi ja ruotsi voivat vähitellen taantua kyökkikieliksi, joita käytetään ainoastaan kodin piirissä.

Englannin kielen vahvistuminen näkyy selvästi myös tutkimuksen kentällä: monien tutkijoiden on helpompi kirjoittaa aiheestaan englanniksi kuin omalla äidinkielellään. Kun yhä suurempi osuus teksteistä tuotetaan suoraan englanniksi, on vaarana ettei tutkimuksen kannalta tarpeellisia uusia käsitteitä enää synny muihin kieliin. Jos alan keskeinen käsitteistö on olemassa vain englanniksi, tieteellinen keskustelu muilla kielillä käy hyvin hankalaksi. Tottumus englanninkielisten tekstien tuottamiseen saattaa johtaa myös siihen, että englannin lauserakenteet ja ilmaisutavat hiipivät myös omalla äidinkielellä kirjoitettuihin teksteihin.

Englanninkielinen julkaiseminen on tärkeää, jotta tutkimustulokset saadaan kansainvälisen tiedeyhteisön ulottuville ja osaksi kansainvälistä keskustelua. Samalla olisi kuitenkin huolehdittava siitä, että myös suomi ja ruotsi säilyvät tieteen kielinä - että tieteellistä keskustelua on jatkossakin mahdollista käydä myös muilla kielillä kuin englanniksi. Eloressa yritämme kantaa korttamme kekoon jatkamalla tutkimusartikkeleiden ja muiden kirjoitusten julkaisemista kotimaisilla kielillä. Pyrimme myös siihen, että julkaistavat tekstit olisi kirjoitettu sujuvasti, englannista peräisin olevia lauserakenteita ja turhaa koukeroisuutta välttäen.

Tämän numeron teemana on lapsuus ja nuoruus muistitiedossa. Ulla Savolainen ja Riikka Taavetti ovat koonneet kolmen artikkelin ja kahden katsauksen kokonaisuuden, jossa lapsuuden ja nuoruuden muistamista käsitellään monesta kiinnostavasta näkökulmasta. Kiitokset teematoimittajille! Julkaisemme myös museoiden, luonnon, kulttuurin ja paikallisidentiteetin suhteita valottavan tutkimusartikkelin sekä videoitua kävelyhaastattelua tutkimusmenetelmänä tarkastelevan katsauksen. Lisäksi mukana on jälleen useita konferenssiraportteja, lektioita ja kirja-arvioita. 
Tässä numerossa julkaisemme pitkästä aikaa myös puheenvuoron. Helmi Järviluoma ja Jari Ruotsalainen tuovat tekstissään esiin niitä haasteita, joita Euroopan unionin uusi tietosuoja-asetus ja yksilönsuojaan liittyvien tulkintojen kiristyminen aiheuttivat Järviluoman johtamalle tutkimushankkeelle. Avoimen tieteen ja yksilönsuojan ihanteiden väliset ristiriidat ja niihin liittyvät käytännön ongelmat lienevät tuttuja monille muillekin tutkijoille, ja siksi aiheesta olisi hyvä käydä julkista keskustelua. Elore ei lehtenä ota kantaa tietosuojasäädösten tulkintaan, mutta tarjoaa mielellään foorumin keskustelulle: toivotamme kaikki Järviluoman ja Ruotsalaisen puheenvuoroon liittyvät näkemykset ja kommentit tervetulleiksi Eloren Facebook-sivulle (https://www.facebook.com/elore.fi/), jolla myös kirjoittajat itse ovat valmiita jatkamaan keskustelua aiheesta.

Julkaisemme mielellämme myös jatkossa puheenvuoroja, jotka käsittelevät Eloren edustamien tieteenalojen kannalta tärkeitä ja ajankohtaisia kysymyksiä. Tekstit voivat olla hyvinkin kantaaottavia, kunhan niissä esitetyt mielipiteet taustoitetaan ja perustellaan. Jos mielessäsi on aihe, josta olisi tärkeää keskustella, tarjoa tekstiä puheenvuoroksi!

Lopuksi kiitokset kaikille syysnumeron kirjoittajille, toimittajille, vertaisarvioijille, toimitussihteerille ja kielentarkistajalle! Nyt on aika rauhoittua syksyn kiireiden jälkeen ja kerätä voimia tulevaan. Toivotamme kaikille rauhallista joulunaikaa ja antoisaa tulevaa vuotta.

\section{Lähteet}

Kotimaisten kielten keskus. 2018. "Suomi tarvitsee pikaisesti kansallisen kielipoliittisen ohjelman." Suomen kielen lautakunnan kannanotto 26.10.2018. https:// www.kotus.fi/ohjeet/suomen kielen lautakunnan suosituksia/kannanotot/ suomi_tarvitsee_pikaisesti_kansallisen_kielipoliittisen_ohjelman. 